\title{
INPUTS OF SEDIMENT AND CARBON TO AN ESTUARINE ECOSYSTEM: INFLUENCE OF LAND USE ${ }^{1}$
}

\author{
Robert W. Howarth, Jean R. Fruci, and Diane Sherman \\ Corson Hall, Section of Ecology \& Systematics, Cornell University, Ithaca, New York 14853 USA
}

\begin{abstract}
Estuaries and coastal marine ecosystems receive large inputs of nutrients, organic carbon, and sediments from non-point-source runoff from terrestrial ecosystems. In the tidal, freshwater Hudson River estuary, such inputs are the major sources of organic carbon, driving ecosystem metabolism, and thus strongly influencing dissolved oxygen concentrations. We used a watershed simulation model (GWLF) to examine the controls on inputs of organic carbon and sediment to this estuary.

The model provides estimates of water discharge, sediment inputs, and organic carbon inputs that agree reasonably well with independent estimates of these fluxes. Even though the watershed for the Hudson River estuary is dominated by forests, the model predicts that both sediment and organic carbon inputs come overwhelmingly from urban and suburban areas and from agricultural fields. Thus changes in land use within the Hudson River basin may be expected to alter inputs to the estuary, thereby altering its metabolism. Precipitation is important in controlling carbon fluxes to the estuary, and so climate change can be expected to alter estuarine metabolism. However, the day-to-day and seasonal patterns of precipitation appear more important than annual mean precipitation in controlling organic carbon fluxes.
\end{abstract}

Key words: carbon; estuaries; estuarine ecosystem; Hudson River; land use; model; sediment.

\section{INTRODUCTION}

Estuaries and coastal marine ecosystems are heavily influenced by human activities and are increasingly being degraded in many regions of the world. The agents of stress are many, and include overfishing, wetland and other habitat destruction, pollution from oil and other toxic substances, and eutrophication and anoxia. These problems have been recognized for some time, and governments throughout the world have taken steps to attempt to regulate such stresses and maintain or even improve the environmental quality of estuaries. Despite such efforts, however, eutrophication, nuisance algal blooms, and the development of anoxic or hypoxic waters have increased in many estuaries and coastal seas, causing serious threats to fishery resources and other wildlife (Larsson et al. 1985, Price et al. 1985, Officer et al. 1986). Eutrophication also has contributed to the loss of submerged vascular plant vegetation, with deleterious effects on fish and waterfowl (Kemp et al. 1983, 1984).

Why have these problems increased despite intensive management efforts? We suggest that water quality management efforts in estuaries have focused too much on improving sewage treatment, and have not dealt adequately with non-point sources of nutrients and organic carbon, that is, exports of substances from terrestrial ecosystems. The scale of non-point-source inputs to estuaries can be seen by considering nitrogen, the element most frequently controlling eutrophication

\footnotetext{
' Manuscript received 31 August 1989; revised 23 March 1990; accepted 30 March 1990.
}

in temperate-zone estuaries and coastal marine ecosystems (Boynton et al. 1982, D'Elia et al. 1986, Howarth 1988). Non-point-source runoff from terrestrial ecosystems frequently accounts for half or more of the total nitrogen inputs to many major estuaries, such as Delaware Bay, Narragansett Bay, and Chesapeake Bay (Nixon and Pilson 1983). Such estuaries are fairly open ecosystems that receive tremendously large nitrogen inputs, often at rates per unit area 1000-fold greater than those applied to heavily fertilized agricultural fields (Nixon et al. 1986).

Have non-point-source supplies of nitrogen and other substances to estuaries been increasing, and if so, why? Have fluxes increased in response to changes in land use, climate, or atmospheric deposition to terrestrial ecosystems? Qualitatively, the answer is probably "yes," but for nitrogen inputs to estuaries, these are difficult questions to address quantitatively, in part because of complexity in the terrestrial cycle. Even in an extremely well studied forested ecosystem such as that at Hubbard Brook, New Hampshire, the factors regulating nitrogen export are poorly known; Likens et al. (1985) found no clear relationship between annual nitrate export and such factors as streamflow, total precipitation, or nitrogen inputs in precipitation over a period of $14 \mathrm{yr}$ in the Hubbard Brook watershed. Agricultural lands tend to export more nitrogen than do forests, but nitrogen exports from agroecosystems are quite variable and are not clearly related to nitrogen inputs in fertilizer (Beaulac and Reckow 1982).

We have chosen to address a set of simpler questions: what controls the non-point-source inputs in carbon and total suspended sediments to an estuary, and how 


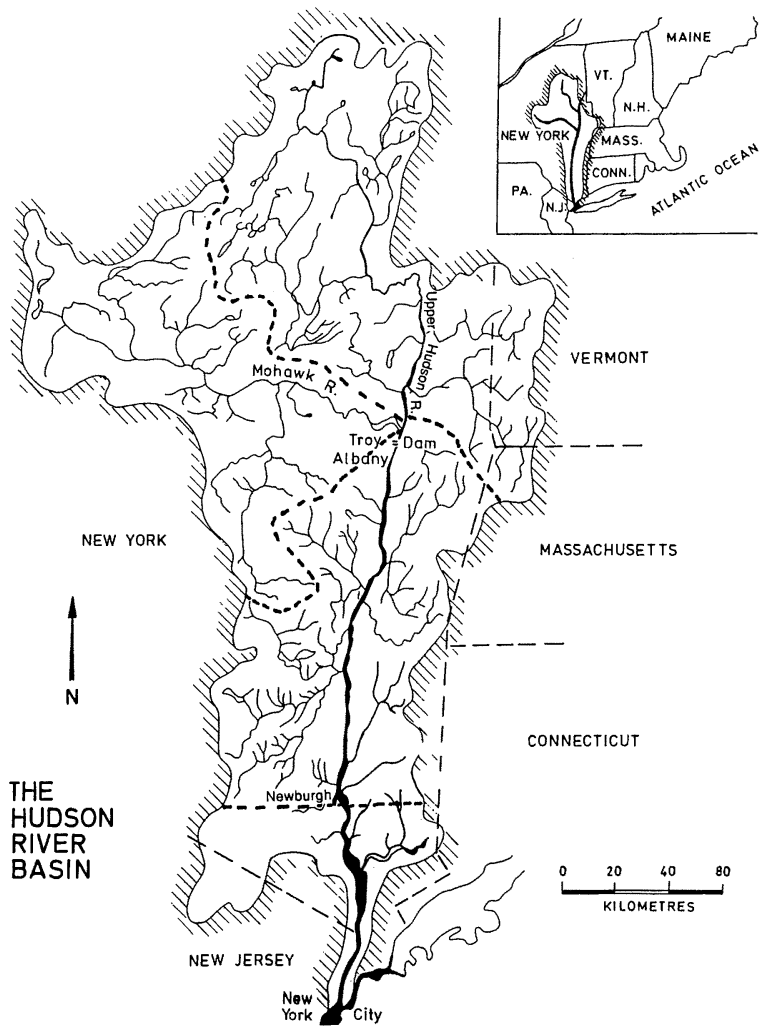

Fig. 1. The Hudson River watershed, composed of the upper Hudson River basin, the Mohawk River basin, and the lower Hudson River basin.

might these be affected by changes in land use or changes in climate? The export of carbon and total sediment from terrestrial ecosystems probably is more predictable than is the export of nitrogen, at least at the scale of small forested watersheds (Fisher and Likens 1973). And although carbon and total sediment inputs are probably of less significance than are nitrogen inputs in most estuaries, they nonetheless can be of importance. For example, in the tidal, freshwater portion of the Hudson River, carbon and total sediment inputs have major influences on ecosystem metabolism and on light penetration (Gladden et al. 1988, Stross and Sokol 1989, R. W. Howarth et al., unpublished data). In this paper, we present the results of a model used to explore the factors controlling carbon and sediment input to the Hudson River estuary.

\section{Description OF THE TIDAL, Freshwater HUDSON RIVER ESTUARY}

The Hudson River drains a watershed of some 3.5 $\times 10^{6}$ ha and flows some $500 \mathrm{~km}$ from its source in the Adirondack Mountains to New York City (Limburg et al. 1986). The river is strongly tidal below the Troy Dam just north of Aibany, New York (Fig. 1). However, salt water rarely penetrates farther north than
TABLE 1. Land use in the sub-basins of the tidal, freshwater Hudson River estuary. Watershed boundaries are estimated as in Fruci and Howarth (1989).

\begin{tabular}{lrrr}
\hline \hline & $\begin{array}{c}\text { Lower } \\
\text { Hudson } \\
\text { River } \\
\text { basin }\end{array}$ & $\begin{array}{c}\text { Upper } \\
\text { Hudson } \\
\text { River } \\
\text { basin }\end{array}$ & $\begin{array}{c}\text { Mohawk } \\
\text { River } \\
\text { basin }\end{array}$ \\
\hline Total area $\left(10^{3}\right.$ ha $)$ & 1367 & 1011 & 677 \\
Percent forested & 63 & 85 & 61 \\
Percent in agriculture & 13 & 6 & 22 \\
Percent in pasture & 2 & 1 & 3 \\
Percent urban/suburban & 22 & 8 & 13 \\
\hline
\end{tabular}

Newburgh, New York (Cooper et al. 1988). Thus, there is a stretch of tidal, freshwater estuary running some $130 \mathrm{~km}$ north from Newburgh to the Troy Dam.

This freshwater portion of the Hudson River estuary is strongly heterotrophic, with rates of whole-ecosystem respiration (R. W. Howarth et al., unpublished data) exceeding net primary production (Cole et al., in press) by at least six-fold. New primary production is fairly low and is light limited (Cole et al., in press), the result of both high turbidity and a relatively deep water column that is well mixed all the way to the bottom (R. W. Howarth et al., unpublished data). Any change in inputs of sediment to the river would be expected to change the turbidity (Stross and Sokol 1989) and therefore alter net primary production, although the effect might be somewhat damped by tidal resuspension of sediment from the bottom.

Respiration in the tidal, freshwater estuary consumes carbon (C) at the rate of some $85 \times 10^{9} \mathrm{~g} / \mathrm{yr}$; much of this respiration is heterotrophic respiration driven by alloch thonous inputs of organic carbon from non-point sources in terrestrial ecosystems (R. W. Howarth et al., unpublished data). Using United States Geological Survey (U.S.G.S.) data for several tributary watersheds within the Hudson River watershed, Gladden et al. (1988) estimated average carbon exports of 3.1 $\mathrm{g} \cdot \mathrm{m}^{-2} \cdot \mathrm{yr}^{-1}$ from the terrestrial ecosystems within the watershed, a value fairly typical for the world's other large rivers (Schlesinger and Melack 1981). Since the area of watershed feeding into the tidal, freshwater estuary and upstream tributaries is some $3.1 \times 10^{6}$ ha (Table 1), this corresponds to a $\mathrm{C}$ input to the tidal, freshwater estuary of $96 \times 10^{9} \mathrm{~g} / \mathrm{yr}$.

Other sources of organic carbon to the river are of smaller magnitude. Net primary production within the tidal, freshwater estuary produces at most $15 \times 10^{9}$ $\mathrm{g} / \mathrm{yr}$, perhaps considerably less (calculated from data in Cole et al. [in press] and Garritt [1990], and including both phytoplankton and macrophyte production). Sewage inputs of carbon to this stretch of the river are relatively small, contributing only $3-5.5 \times 10^{9} \mathrm{~g} / \mathrm{yr}$ (including inputs of 1.4-2.4 $\times 10^{9} \mathrm{~g} / \mathrm{yr}$ to waters upstream of the Troy Dam; Fruci and Howarth 1989).

Our estimates for sewage input do not consider discharges from New York City or other discharges below 
the estuarine salt wedge; organic carbon in these inputs can move no farther upriver than does salt water and so does not influence the tidal, freshwater estuary. However, carbon inputs to freshwater portions of the river and estuary can flow downriver into the saline estuary. Sewage discharges of carbon into the saline portion of the estuary probably are $\approx 5.3 \times 10^{9} \mathrm{~g} / \mathrm{yr}$ (assuming complete secondary treatment) to $35 \times 10^{9}$ $\mathrm{g} / \mathrm{yr}$ (assuming no sewage treatment; Fruci and Howarth 1989, Limburg et al. 1986). Thus, even in the saline estuary including New York City harbor, nonpoint-source inputs of carbon from upstream terrestrial ecosystems significantly exceed sewage inputs.

The heterotrophic nature of the estuary results in lowered oxygen levels. Oxygen concentrations in the tidal, freshwater portions of the Hudson River estuary are commonly as low as $65-70 \%$ of saturation (R. W. Howarth et al., unpublished data) and often are even lower in the bottom waters of the stratified saline portion of the estuary, where hypoxic conditions are prevalent (City of New York 1987). This is of great concern since the estuary and its tributaries are a major spawning and nursery ground for several species of fish. The Hudson River estuary supports the last major spawning stock of striped bass (Morone saxatilis) on the east coast of North America; striped bass spawning stocks from other major estuaries such as Chesapeake Bay have severely declined, with increasing anoxia suggested as one possible cause (Price et al. 1985). Will increases in organic carbon inputs to the estuary occur as a result of land-use or climate change, further lowering oxygen concentrations as respiration increases?

\section{STRUCTURE AND PARAMETERIZATION OF THE MODEL}

We have used a modeling approach as a start toward determining the factors controlling inputs of organic carbon and total sediment to the tidal, freshwater Hudson River estuary from terrestrial ecosystems. We used a generalized watershed loading model (GWLF) developed by Haith and Shoemaker (1987). We obtained a BASIC version of the GWLF model from Haith and developed input parameters and data for the Hudson River watershed. We applied the model to a much larger scale than that used by Haith and Shoemaker (1987): watersheds having areas of $677 \times 10^{3}-1.37 \times$ $10^{6}$ ha rather than $85 \times 10^{3}$ ha. We also modified the model to examine carbon fluxes rather than nitrogen and phosphorus fluxes. The model was run on an IBMXT.

We separately modeled three sub-basins within the watershed feeding the tidal, freshwater estuary: the Mohawk River basin, the upper Hudson River basin, and the lower Hudson River basin (Fig. 1). The upper Hudson River basin is defined as the watershed feeding that portion of the Hudson River above the Troy Dam. The Mohawk River and upper Hudson join just above the Troy Dam and together make up the flow of water over that dam into the upper reaches of the tidal, freshwater estuary (Fig. 1). We have defined the lower Hudson River basin as the watershed directly feeding into the tidal, freshwater estuary (excluding inputs directly into the saline estuary and inputs that enter the Hudson River above the Troy Dam in the non-estuarine portion of the river). All of the basins are dominated by forests, but the lower Hudson River basin and Mohawk River basin are somewhat more developed than is the upper Hudson River basin (Table 1). Urban and suburban areas are the second largest land-use type in the lower Hudson River basin, while row-crop agriculture is the second largest land-use type in the Mohawk River basin. Pasture lands are a minor component of all three sub-basins.

The model as we have applied it can be thought of as three sub-models (Figs. 2-4). Two of these apply to forest and agricultural lands, and within these submodels, forest lands, land in row agriculture, and pasture lands are considered separately. The other submodel applies to urban and suburban areas. The model treats land-use areas as aggregated within each of the sub-basins. Data on forest and agricultural areas were obtained from reports from the State of New York (New York State Department of Environmental Conservation 1981, New York Crop Reporting Service 1985). Areas of urban and suburban lands were calculated by difference. The relatively small area of Hudson River watershed within the states of Vermont, Massachusetts, and Connecticut was ignored.

\section{Rural water balance model}

This sub-model uses a mass-balance approach for water in forest and agricultural lands (Fig. 2). Actual daily data on precipitation and temperature from 53 National Oceanic and Atmospheric Administration weather stations within the Hudson River watershed are used to calculate average meteorological conditions in each of three sub-basins within the watershed for the tidal, freshwater Hudson River estuary (Fruci and Howarth 1989). These average meteorological conditions drive the water balance model, using a time step of $1 \mathrm{~d}$. Surface runoff is calculated from the Curve Number Equation of the United States Soil Conservation Service (Ogrosky and Mockus 1964, Mockus 1972, U.S. Soil Conservation Service 1975):

$$
Q_{t}=\left(R_{t}+M_{t}-0.2 W_{t}\right)^{2} /\left(R_{t}+M_{t}-0.8 W_{t}\right),
$$

where $Q_{t}$ is the runoff on day $t, R_{t}$ is the rainfall on day $t, M_{t}$ is the snowmelt on day $t$, and $W_{t}$ is the retention parameter of the watershed on day $t$. The water retention parameter, $W_{t}$, determines whether water runs off or is stored in the soil. It is a complex function of rainfall and snowmelt in the preceding 5-d period; as the amount of rain and snowmelt in the preceding $5 \mathrm{~d}$ increases, proportionately more water runs off. The retention parameter is estimated separately for different land uses and for the growing season vs. dormant 


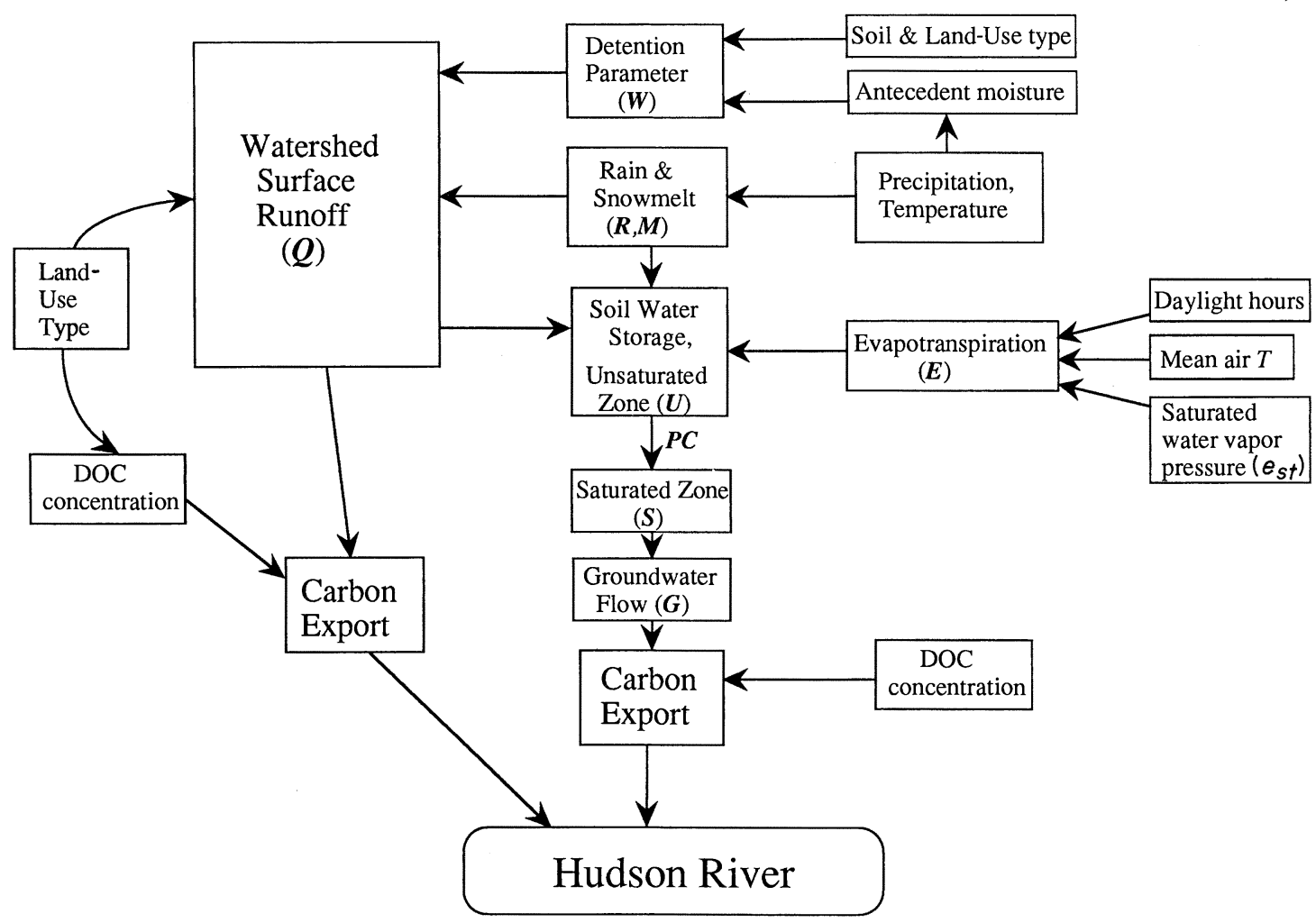

FIG. 2. Rural water balance sub-model for forest and agricultural lands. DOC $=$ dissolved organic carbon.

season. Further details on this parameter are provided in Haith and Shoemaker (1987) and Fruci and Howarth (1989).

The model partitions precipitation into either rainfall $\left(R_{t}\right)$ or snowfall depending upon whether the temperature is above or below freezing. A separate equation keeps track of snow accumulation; snow is removed by melting $\left(M_{t}\right)$, which is a simple linear function of daily temperature. We follow Haith and Shoemaker (1987) and use a value of $0.45 \mathrm{~cm}$ liquid water per day per degree above $0^{\circ} \mathrm{C}$ for a melt constant, a value in the middle of the range reported by Linsley et al. (1958).

In our use of the GWLF model we considered groundwater as two reservoirs: the surface unsaturated zone that generally does not have all soil pores full of water, and a deeper saturated zone where all soil pores are full. The water mass-balance equation for the unsaturated zone is:

$$
U_{t+1}=U_{t}+I_{t}-E_{t}-P C_{t},
$$

where $U_{t+1}$ and $U_{t}$ are the moisture contents of the surface unsaturated soil zone in excess of field capacities on day $t+1$ and day $t$, respectively, $I_{t}$ is the amount of water that infiltrates on day $t, E_{t}$ is the amount of water evapotranspired on day $t$, and $P C_{t}$ is the amount of percolation into the deeper saturated zone on day $t$. Our model runs start in April and assume that initially the soil is at field capacity, that is, $U_{t}=$
0 (Haith and Shoemaker 1987). The amount of infiltrating water, $I_{t}$, is the difference between the sum of rainfall and meltwater, and runoff:

$$
I_{t}=\left(R_{t}+M_{t}\right)-Q_{t} .
$$

Evapotranspiration is assumed to be zero for temperatures at or below freezing. For temperatures above freezing, potential evapotranspiration is estimated from the Hamon (1961) equation:

$$
P E_{t}=\left(0.021 D_{t}^{2}\right)\left(e_{s t}\right) / T_{t},
$$

where $P E_{t}$ is potential evapotranspiration, $D_{t}$ is the number of daylight hours on day $t, e_{s t}$ is the saturated water vapor pressure on day $t$, and $T_{t}$ is the absolute temperature on day $t$. Actual evapotranspiration is taken as a linear function of potential evapotranspiration and a cover coefficient (Haith and Shoemaker 1987). Average daylight hours for each month and an equation for estimating saturated water vapor pressure are given in Fruci and Howarth (1989).

The mass-balance equation for water in the deeper, saturated zone is:

$$
S_{t+1}=S_{t}+P C_{t}-G_{t},
$$

where $S_{t+1}$ and $S_{t}$ are the moisture contents on an areal basis of the saturated zone on day $t+1$ and day $t$, respectively, and $G_{t}$ is the amount of water flowing from the saturated zone to a stream or river on day $t$. 


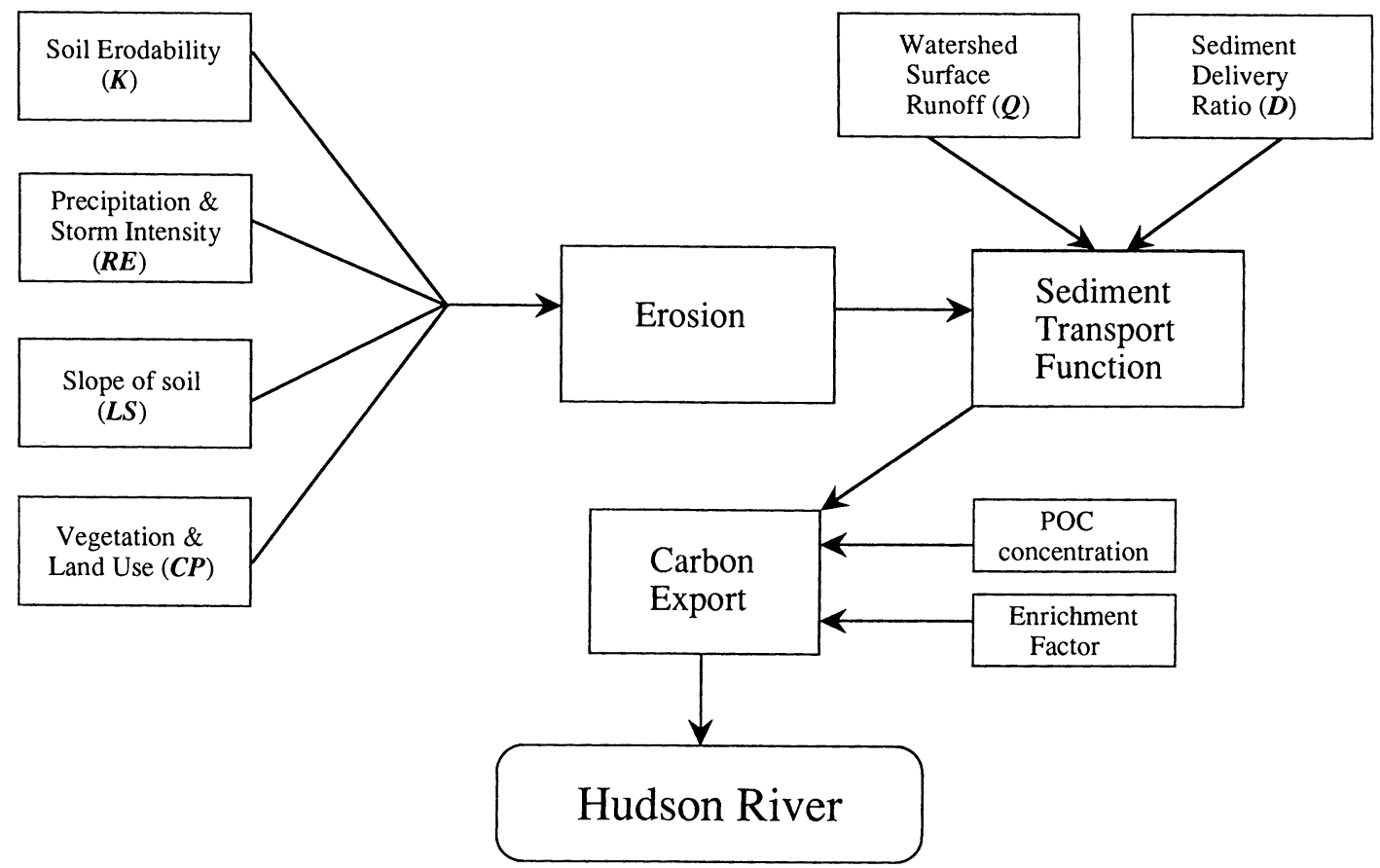

FIG. 3. Rural sediment sub-model for forest and agricultural lands. POC = particulate organic carbon.

At the start of each model run we used an arbitrarily selected value of $3 \mathrm{~cm}$ for $S_{t}$ and ran the first year of the run twice, discarding the output for the first run of the first year; this allows a reasonable calibration of saturated-zone moisture content in the absence of any direct data (Haith and Shoemaker 1987).

The movement of water from the saturated zone to streams and rivers, $G_{t}$, is taken as a linear function of the moisture content of the saturated zone:

$$
G_{t}=(r)\left(S_{t}\right) .
$$

For the Hudson River watershed, we estimated the recession constant, $r$, by repeatedly running the model using three years of meteorological data (1983-1986) and choosing a value of $r$ that minimized year-to-year variation in streamflow and that produced no months to zero streamflow (Fruci and Howarth 1989). Total streamflow is calculated as the sum of groundwater flow, $G_{t}$, and surface runoff, $Q_{t}$, summed over all landuse types.

To estimate the movement of dissolved organic carbon (DOC) in runoff and groundwater, these water flows are multiplied by an assumed DOC concentration. Surface runoff is assigned a DOC concentration as a function of land-use type. For forest lands, we assumed that runoff had a DOC concentration of 1.4 $\mathrm{mg} / \mathrm{L}$, the annual mean value reported by Fisher and Likens (1973) for eight sites monitored in a tributary stream at Hubbard Brook, New Hampshire. For agricultural lands, runoff was assumed to have a DOC concentration of $6.9 \mathrm{mg} / \mathrm{L}$, the average value for runoff from conventional till plots following storm events in an agricultural experiment station in Mississippi (Schreiber and McGregor 1979). All groundwaters are assumed to have a DOC concentration of $0.7 \mathrm{mg} / \mathrm{L}$, the median value reported by Thurman (1985). All DOC exports are assumed to enter the Hudson River estuary. Our particular assumptions for DOC concentrations are somewhat arbitrary, but were tested as part of a sensitivity analysis of the model, discussed below (see Sensitivity analyses). See Fruci and Howarth (1989) for further discussion of these assumptions.

\section{Rural sediment model}

The GWLF sub-model for sediments (Fig. 3) is based in part on the Universal Soil Loss Equation (Stewart et al. 1976, Wischmeier and Smith 1978, Haith 1985, Haith and Shoemaker 1987). For each of the rural landuse types (forests, row-crop agriculture land, and pastures) in each of the three sub-basins of the watershed for the tidal, freshwater Hudson River estuary, soil erosion is estimated from the equation:

$$
X_{t}=0.132\left(R E_{t}\right)(A)(K)(L S)(C)(P),
$$

where 0.132 is a dimensional conversion factor, $R E_{t}$ is the rainfall erosivity on day $t, A$ is the area of the particular land type in a particular sub-basin, $K$ is the soil erodibility factor, $L S$ is the topographic factor (slope length and steepness), $C$ is the vegetation cover factor, and $P$ is the agricultural practice factor. Rainfall erosivity is modeled after Richardson et al. (1983):

$$
R E_{t}=64.6 a\left(R_{t}^{1.81}\right),
$$


where $a$ is a variable that is a function of storm energy and intensity. For New York State, reasonable values of $a$ are $0.09 \mathrm{MJ} \cdot \mathrm{cm} \cdot \mathrm{ha}^{-1} \cdot \mathrm{h}^{-1}$ during the dormant season and $0.34 \mathrm{MJ} \cdot \mathrm{cm} \cdot \mathrm{ha}^{-1} \cdot \mathrm{h}^{-1}$ during the growing season (Richardson et al. 1983); we used these values in our standard model runs.

We used information from Cline and Marshall (1976) and Wischmeier and Smith (1978) to estimate soil erodibility, $K$, and soil topographic factors, $L S$, for soils in the Hudson River basin. Including all classes of soil erodibility and slopes, we calculated a range of values for the product $(K)(L S)$ of 0.06 to 2.21 with a median value of 1.14 (Fruci and Howarth 1989). Most of the soils in the watershed are of moderate erodibility; assuming moderate erodibility, we obtained a range of values for the product $(K)(L S)$ of 0.1 to 1.45 with a median value of 0.78 . We used this median value of 0.78 . We used this median value for moderately erodible soils in our standard model runs.

Values for vegetative cover factors, $C$, and for agricultural practice factors, $P$, can be obtained from McElroy et al. (1976) and Wischmeier and Smith (1978). For row-crop agricultural fields, we assumed that at least some erosion-curtailing practices are employed and that the steepest slopes are not farmed; these assumptions yielded a range of values for the product $(C)(P)$ of 0.2 to 0.45 (Fruci and Howarth 1989). We used a value of 0.32 for our standard model runs for row-crop agricultural lands. For permanent pasture, we chose to use a $(C)(P)$ value of 0.06 in our standard model runs; this is representative of fields covered by a mixture of grasses, weeds, and brush (Wischmeier and Smith 1978). For forests, we chose a standard value of $(C)(P)$ of 0.001 ; this is at the high end of values for forests and so probably overestimates erosion from forests (Wischmeier and Smith 1978).

The model estimates transport of eroded sediment on a monthly basis by allocating the total annual eroded sediment in proportion to a transport factor; this factor for each month is the sum of daily runoff raised to the $5 / 3$ power for each day of the month, $Q_{t}{ }^{5 / 3}$ (Haith and Shoemaker 1987). Since in this paper we only report annual summed rates of erosion, our conclusions are completely independent of the assumptions behind monthly transport rates.

Only a small proportion of the eroded sediment actually is transported to the Hudson River. The amount transported is the product of the total amount of eroded material (that is, the annual sums of $X_{t}$ for each land type) and the sediment delivery ratio, $D$. For our standard model runs we have assumed a value of 0.01 for $D$. Actual values for $D$ have never been determined for basins much larger than $100 \times 10^{3}$ ha (Vanoni 1975). The basins we are modeling range in area from $677 \times 10^{3}$ ha for the Mohawk River to $1.37 \times 10^{6}$ ha for the lower Hudson River. Thus, we have been forced to extrapolate from smaller watershed studies, using the relationship that $D$ decreases as drainage areas in- crease approximately according to the 0.2 power of drainage area (Renfro 1975, Vanoni 1975, Stewart et al. 1976). This is obviously a crude approximation, and, in fact, $D$ can vary seasonally (Sheridan et al. 1982) and varies with watershed geomorphology (Renfro 1975).

The amount of particulate organic carbon (POC) exported from watersheds to the Hudson River estuary is the product of total sediment transported, the percentage of carbon in bulk soil, and an enrichment ratio. The enrichment ratio corrects for the fact that the smaller, more easily eroded soil particles have a higher carbon content than does the average bulk soil. We have chosen an enrichment ratio of three for our standard model runs, a value typical for moderately erodible soils (McElroy et al. 1976, Stewart et al. 1976). We have used soil maps in McElroy et al. (1976) to estimate that average bulk soils in the Hudson River drainage basins are $3 \%$ carbon by mass.

\section{Urban/suburban model}

In this GWLF sub-model, groundwater export from urban and suburban areas is estimated exactly as for rural areas, with all of the same assumptions (Haith and Shoemaker 1987). However, DOC and POC export in surface runoff are handled differently than in the rural models and are aggregated in one estimate of total organic carbon (TOC) export (Fig. 4). This portion of the model was originally developed as the STORM model by the United States Army Corps of Engineers (Hydraulic Engineering Center 1977). Erodible sediment and TOC are produced at linear rates. For our standard model runs, we assume a sediment production rate of $1.21 \mathrm{~kg} \cdot \mathrm{ha}^{-1} \cdot \mathrm{yr}^{-1}$ and a TOC production rate of $52.4 \mathrm{~g} \cdot \mathrm{ha}^{-1} \cdot \mathrm{yr}^{-1}$. This is based on the assumption that urban/suburban areas are $60 \%$ low-density residential, $20 \%$ medium-density residential, and $20 \%$ high-density residential.

The urban/suburban sub-model assumes that all of the sediment and TOC produced annually are washed into the Hudson River estuary, with a $100 \%$ delivery efficiency. This is probably reasonable since most urban and suburban areas are near the river or its tributaries and since road and storm sewer systems act as very efficient movers of sediment. The monthly pattern of sediment and TOC transport is controlled by a transport factor that is proportional to $Q_{t}^{5 / 3}$, exactly as for the rural sediment model. However, as with the rural sediment model, we only report estimates of annual rates of sediment and TOC transport in this paper. These annual estimates are not affected by the assumptions concerning monthly transport rates.

\section{ESTIMATES OF WATER DischaRge AND SEDIMENT FLUXES FROM THE STANDARD MODEL RuN}

Table 2 presents estimates of total water discharge and of total sediment export from terrestrial ecosys- 


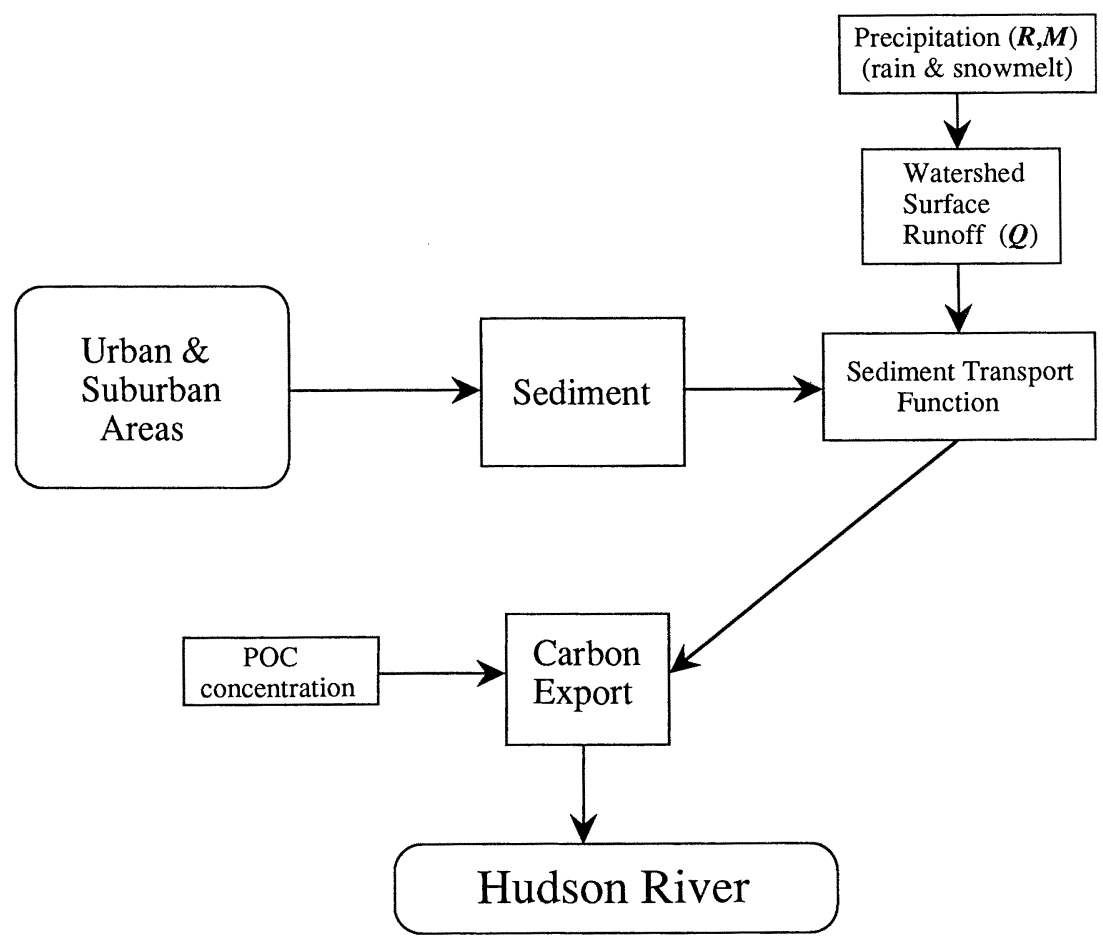

FIG. 4. Urban and suburban sub-model. $\mathrm{POC}=$ particulate organic carbon.

tems to the estuary from the standard model run for 3 yr from April 1983 through March 1986; all values are annual means for the $3 \mathrm{yr}$. A rough calibration test of our model is possible by comparing the combined model estimates for the upper Hudson River basin and Mohawk River basin with United States Geological Survey (U.S.G.S.) data from a gauging station at Green Island, a site near the Troy Dam where the two river basins converge. In addition to water discharge measurements, monthly samples for total suspended sediments and for organic carbon concentrations were taken from October 1979 through September 1981 at this station (U.S.G.S. 1980, 1981). The average model run predicts combined water discharges from the upper Hudson River basin and Mohawk River basin of 10.5 $\times 10^{9} \mathrm{~m}^{3} / \mathrm{yr}$ and combined sediment exports from these basins of $200 \times 10^{9} \mathrm{~g} / \mathrm{yr}$ (Table 2). Actual U.S.G.S. data at Green Island indicate an average water discharge of $12.2 \times 10^{9} \mathrm{~m}^{3} / \mathrm{yr}$ and suspended sediment flux of $265 \times 10^{9} \mathrm{~g} / \mathrm{yr}$. Thus, our model predictions are $86 \%$ of measured water discharge and $75 \%$ of measured suspended sediment flux.

We have made no attempt to fine-tune the model to fit the U.S.G.S. data by changing model parameters since there is no unique procedure for doing so. For example, sediment export in the model could be raised by increasing the sediment delivery ratio, $D$, or by increasing the ratio of heavily urbanized to moderately or lightly urbanized land (see Sensitivity analyses, below). Rather, all of our input parameters were chosen on the basis of our best judgment and knowledge of the Hudson River basins. We consequently are quite pleased with the agreement between model estimates and U.S.G.S. data.

Our model results suggest that most of the sediment inputs to the Hudson River estuary come from rowcrop agricultural lands and from urban and suburban lands; forests and pasture lands are very minor sources. If anything, we overestimated erosion from forests since we chose arrelatively high value of $C$ for the Universal

TABLE 2. Model-derived estimates of annual water discharge and total sediment inputs from each subbasin, by land-use type.

\begin{tabular}{lccc}
\hline \hline & $\begin{array}{c}\text { Lower Hudson } \\
\text { River basin }\end{array}$ & $\begin{array}{c}\text { Upper Hudson } \\
\text { River basin }\end{array}$ & $\begin{array}{c}\text { Mohawk River } \\
\text { basin }\end{array}$ \\
\hline Water discharge $\left(10^{9} \mathrm{~m}^{3}\right)$ & 5.58 & 6.46 & 4.02 \\
Total sediment, forest $\left(10^{9} \mathrm{~g}\right)$ & 1.89 & 1.50 & 0.71 \\
Total sediment, agriculture $\left(10^{9} \mathrm{~g}\right)$ & 110 & 35.7 & 81.8 \\
Total sediment, pasture $\left(10^{9} \mathrm{~g}\right)$ & 3.87 & 2.16 & 1.57 \\
Total sediment, urban $/$ suburban $\left(10^{9} \mathrm{~g}\right)$ & 142 & 36.8 & 40.9 \\
\hline
\end{tabular}


TABLE 3. Model-derived estimates of organic carbon inputs in $10^{9}$ grams per year from each sub-basin, by land-use type $\mathrm{DOC}=$ dissolved organic carbon; $\mathrm{POC}=$ particulate organic carbon; TOC $=$ total organic carbon.

\begin{tabular}{|c|c|c|c|c|}
\hline & $\begin{array}{l}\text { Lower Hudson } \\
\text { River basin }\end{array}$ & $\begin{array}{l}\text { Upper Hudson } \\
\text { River basin }\end{array}$ & $\begin{array}{c}\text { Mohawk River } \\
\text { basin }\end{array}$ & Total \\
\hline \multicolumn{5}{|l|}{ Surface runoff of DOC } \\
\hline $\begin{array}{l}\text { Forests } \\
\text { Agriculture } \\
\text { Pasture }\end{array}$ & $\begin{array}{l}1.10 \\
1.31 \\
0.183\end{array}$ & $\begin{array}{l}1.12 \\
0.586 \\
0.055\end{array}$ & $\begin{array}{l}0.515 \\
1.37 \\
0.126\end{array}$ & $\begin{array}{l}2.73 \\
3.26 \\
0.364\end{array}$ \\
\hline \multicolumn{5}{|l|}{ Surface runoff of POC } \\
\hline $\begin{array}{l}\text { Forests } \\
\text { Agriculture } \\
\text { Pasture }\end{array}$ & $\begin{array}{l}0.170 \\
9.93 \\
0.349\end{array}$ & $\begin{array}{l}0.135 \\
3.22 \\
0.081\end{array}$ & $\begin{array}{l}0.064 \\
7.36 \\
0.194\end{array}$ & $\begin{array}{c}0.369 \\
20.5 \\
0.624\end{array}$ \\
\hline $\begin{array}{l}\text { Surface runoff of TOC from } \\
\text { urban/suburban }\end{array}$ & 9.89 & 2.55 & 2.84 & 15.3 \\
\hline DOC from groundwater & 4.34 & 3.82 & 2.32 & 10.5 \\
\hline Total carbon & 27.3 & 11.6 & 14.8 & 53.6 \\
\hline
\end{tabular}

Soil Loss Equation (see Structure and parameterization ... : Rural sediment model, above). Forests make up most of the land area in all three sub-basins (Table 1), and so the differences in forests, agricultural fields, and urban and suburban lands as sediment sources per unit are even more pronounced. We have insufficient confidence in the details of the model, particularly as applied to urban and suburban lands, to reach any firm conclusions on the relative importance of agricultural fields vs. urban/suburban lands as sources of sediment.

\section{Estimates of Organic Carbon FluXes from THE STANDARD MOdEL RUN}

Our standard model run predicts that total carbon inputs to the tidal, freshwater Hudson River estuary from non-point sources are $54 \times 10^{9} \mathrm{~g} / \mathrm{yr}$ (Table 3). As stated in the introduction, we believe total carbon inputs to the estuary from non-point sources are actually more in the range of $96 \times 10^{9} \mathrm{~g} / \mathrm{yr}$. Our model estimates are $55 \%$ of this amount. Our model estimate for organic carbon coming over the Troy Dam from the upper Hudson River basin and Mohawk River ba$\sin$ is $26 \times 10^{9} \mathrm{~g} / \mathrm{yr}$, or $60 \%$ of the flux of $47 \times 10^{9}$ $\mathrm{g} / \mathrm{yr}$ calculated from U.S.G.S. data $(1980,1981)$ at the Green Island station (after correcting for pointsource inputs of $2 \times 10^{9} \mathrm{~g} / \mathrm{yr}$ to these basins; see $D e$ scription of the tidal, freshwater Hudson River estuary, above). Although the organic carbon prediction is not as close as those for water discharge and total sediment inputs, we consider this to be surprisingly good agreement for a completely independent check without any fine tuning of the model.

The model predicts (Table 3) that the three largest sources of organic carbon are (in decreasing order) POC runoff in eroded materials from agricultural fields, TOC runoff from urban and suburban lands, and DOC in groundwater (combined from all land-use types). Smaller but significant sources of organic carbon are DOC runoff from agricultural fields and from forests
(Table 3). Even though our estimate of POC runoff from forests is probably an overestimate, this is a very minor source. Pasture lands are also a minor source of carbon. Overall, organic carbon inputs to the tidal, freshwater Hudson River estuary from non-point sources are dominated by row-crop agricultural and urban/suburban land uses (Fig. 5). The total land areas in these two types of land use are similar in the combined sub-basins of the river (Table 1; Fig. 5), so the model suggests that per unit area of land, agricultural fields export somewhat more organic carbon than do urban/suburban areas. However, we have insufficient confidence in the details of the urban/suburban model to be comfortable with this as a firm conclusion.

In comparing the sub-basins, the model predicts the largest non-point-source inputs of carbon are from the lower Hudson River basin, with the upper Hudson River basin and Mohawk River basin being comparable sources (Table 3). However, the lower Hudson basin also has the largest area (Table 1). Average carbon exports per unit land area (including all land-use types) are very similar for the lower Hudson River basin and Mohawk River basins, 20 and $22 \mathrm{~kg} / \mathrm{ha}$ respectively, but somewhat less from the upper Hudson River basin, $11 \mathrm{~kg} / \mathrm{ha}$. This pattern is to be expected since the upper Hudson River basin is the most forested and has the least agricultural land and urban/ suburban development. However, an analysis of U.S.G.S. data for the upper Hudson River basin and Mohawk River basin indicated no significant differences in carbon export per unit area from these two basins (Gladden et al. 1988). The data are few, limiting the strength of the comparison, but clearly any detailed conclusion relating carbon export to land use drawn from the model should be treated cautiously. As discussed below (see Model improvements), we may need to model in-stream and in-river processes to obtain more realistic results. For instance, the Mohawk River may have a longer water-residence time and less kinetic energy than the upper Hudson River, resulting in more 
Hudson River Watershed Land use

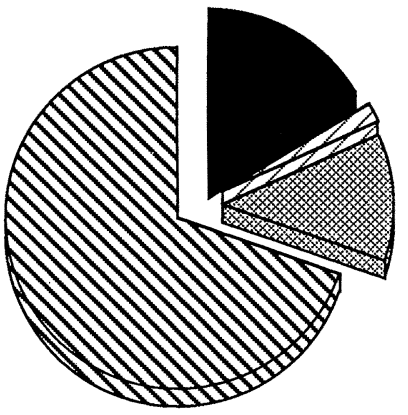

Carbon Export from the

Hudson River Watershed

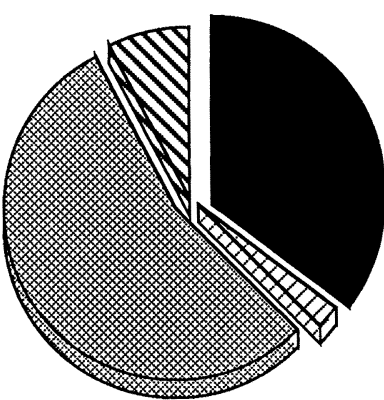

FIG. 5. Land-use patterns and carbon export from the Hudson River watershed.

sedimentation of particles and greater consumption of organic carbon within the river itself.

Gladden et al. (1988) noted a strong correlation between daily water discharges and daily organic carbon exports, both expressed per unit area of watershed, for a variety of tributary watersheds in the Hudson River basin. This led them to suggest that "organic carbon inputs to the estuary may vary substantially from year to year because of the large annual variation in freshwater flow." Our model results also suggest reasonably large year-to-year variations in carbon inputs as a result of variability in precipitation and freshwater flow (Table 4). However, carbon export may be even more sensitive to the seasonal and day-to-day patterns in precipitation than to annual amounts of precipitation. Comparing the runs for 1983-1984 and 1984-1985, we see that annual mean precipitation throughout the sub-basins was $13 \%$ higher in 1983-1984, but the model predicted higher POC and slightly higher TOC exports in 1984-1985, the year with lower annual rainfall. Comparing the runs for 1984-1985 and 1985-1986, precipitation was only $3.7 \%$ higher in 1984-1985, but the model predicted total organic carbon export to be $19 \%$ greater (Table 4). We believe it is reasonable that day-to-day and seasonal precipitation patterns are more important than total annual precipitation in determining fluxes of organic carbon, since erosion and groundwater flow are most sensitive to these shorter period patterns. One needs to take into consideration changes in such patterns if one is to predict the consequences of global and regional climate change on the movement of substances through the landscape to estuaries.

\section{SENSITIVITY ANAlyses}

Although we have made no effort to fine-tune the model by changing parameters to fit the U.S.G.S. data, we have tested the sensitivity of the model to changes in many of the key parameters. In Table 5, the parameter values marked with an asterisk are the values used in the standard model runs. The other values represent reasonable values, but ones that seem less valid to us.
For instance, for the sediment accumulation rate for urban/suburban areas, our standard model run uses a value of $1.21 \mathrm{~kg} \cdot \mathrm{ha}^{-1} \cdot \mathrm{yr}^{-1}$; a value of 0.235 would represent an urban/suburban landscape composed entirely of low-density residential development, whereas a value of 4.66 would represent completely high-density residential lands in urban/suburban areas (Hydraulic Engineering Center 1977).

Increasing the values for virtually any of the tested parameters yields predicted organic carbon fluxes over the Troy Dam that are closer to the average value calculated from the U.S.G.S. $(1980,1981)$ data of 47 $\times 10^{9} \mathrm{~g} / \mathrm{yr}$. However, increasing the values for many of these parameters increases the estimate for total sediment delivered over the Troy Dam to values that are too high compared to the U.S.G.S.-derived estimate of $265 \times 10^{9} \mathrm{~g} / \mathrm{yr}$. If one were inclined to alter model parameters to fit the U.S.G.S. data better, it would appear that the best approach would be to increase the enrichment ratio or the assumed concentration of DOC in runoff; all of the other changes affect total sediment flux more than carbon flux, and standard runs of the model already predict total sediment yield better than they do carbon flux. However, no reasonable increase in the enrichment ratio or in the assumed concentration of DOC in runoff would bring

TABLE 4. Annual estimates of total carbon inputs $\left(10^{9} \mathrm{~g} / \mathrm{yr}\right)$ to the tidal, freshwater Hudson River estuary as predicted from the model. All three sub-basins are combined. DOC $=$ dissolved organic carbon; $\mathrm{POC}=$ particulate organic carbon.

\begin{tabular}{|c|c|c|c|c|}
\hline & $\begin{array}{l}\text { Precipi- } \\
\text { tation } \\
(\mathrm{cm})\end{array}$ & $\begin{array}{l}\text { Predicted } \\
\text { DOC } \\
\text { delivery } \\
\text { (surface } \\
\text { and ground- } \\
\text { water) }\end{array}$ & $\begin{array}{c}\text { Predicted } \\
\text { POC } \\
\text { delivery }\end{array}$ & $\begin{array}{c}\text { Predicted } \\
\text { total C } \\
\text { delivery }\end{array}$ \\
\hline $\begin{array}{l}1983-1984 \\
1984-1985 \\
1985-1986\end{array}$ & $\begin{array}{l}128 \\
113 \\
109\end{array}$ & $\begin{array}{l}20 \\
16 \\
14\end{array}$ & $\begin{array}{l}36 \\
41 \\
34\end{array}$ & $\begin{array}{l}56 \\
57 \\
48\end{array}$ \\
\hline
\end{tabular}


TABLE 5. Representative sensitivity analyses for the model. Values are average for 3-yr runs of the model (1983-1986). The upper Hudson and Mohawk River basins are combined to facilitate comparison with United States Geological Survey data at the Troy Dam. Values are also given for all three sub-basins combined.

\begin{tabular}{|c|c|c|c|c|c|c|}
\hline \multirow[b]{2}{*}{ Model parameters } & \multicolumn{2}{|c|}{ Parameter value } & \multicolumn{2}{|c|}{$\begin{array}{l}\text { Total carbon input } \\
\left(10^{9} \mathrm{~g} / \mathrm{yr}\right)\end{array}$} & \multicolumn{2}{|c|}{$\begin{array}{c}\text { Total sediment input } \\
\left(10^{9} \mathrm{~g} / \mathrm{yr}\right)\end{array}$} \\
\hline & $\begin{array}{c}\text { Dormant } \\
\text { season }\end{array}$ & $\begin{array}{l}\text { Growing } \\
\text { season }\end{array}$ & $\begin{array}{c}\text { Upper } \\
\text { Hudson and } \\
\text { Mohawk }\end{array}$ & $\begin{array}{c}\text { All } \\
\text { sub-basins }\end{array}$ & $\begin{array}{l}\text { Upper } \\
\text { Hudson and } \\
\text { Mohawk }\end{array}$ & $\begin{array}{c}\text { All } \\
\text { sub-basins }\end{array}$ \\
\hline $\begin{array}{l}a \text { (storm energy, intensity) } \\
\left(\mathrm{MJ} \cdot \mathrm{cm}^{-1} \cdot \mathrm{ha}^{-1} \cdot \mathrm{h}^{-1}\right)\end{array}$ & $\begin{array}{l}0.09^{*} \\
0.18\end{array}$ & $\begin{array}{l}0.34^{*} \\
0.68\end{array}$ & $\begin{array}{l}26 \\
37\end{array}$ & $\begin{array}{l}54 \\
74\end{array}$ & $\begin{array}{l}200 \\
323\end{array}$ & $\begin{array}{l}459 \\
698\end{array}$ \\
\hline $\begin{array}{l}(K)(L S)(C)(P) \dagger \\
\quad \text { (land-use characteristics) }\end{array}$ & \multicolumn{2}{|c|}{$\begin{array}{l}0.15 \\
0.25^{*} \\
0.35\end{array}$} & $\begin{array}{l}22 \\
26 \\
31\end{array}$ & $\begin{array}{l}45 \\
54 \\
62\end{array}$ & $\begin{array}{l}153 \\
200 \\
249\end{array}$ & $\begin{array}{l}368 \\
459 \\
551\end{array}$ \\
\hline Enrichment ratio & \multicolumn{2}{|c|}{$\begin{array}{l}2 \\
3 *\end{array}$} & $\begin{array}{l}23 \\
26\end{array}$ & $\begin{array}{l}46 \\
54\end{array}$ & $\begin{array}{l}200 \\
200\end{array}$ & $\begin{array}{l}459 \\
459\end{array}$ \\
\hline Sediment accumulation rate & \multicolumn{2}{|c|}{$\begin{array}{l}0.235 \\
1.21^{*} \\
4.66\end{array}$} & $\begin{array}{l}22 \\
26 \\
40\end{array}$ & $\begin{array}{l}45 \\
54 \\
83\end{array}$ & $\begin{array}{l}131 \\
200 \\
422\end{array}$ & $\begin{array}{r}274 \\
459 \\
1086\end{array}$ \\
\hline$D$ (sediment delivery ratio) & \multicolumn{2}{|c|}{$\begin{array}{l}0.01^{*} \\
0.02\end{array}$} & $\begin{array}{l}26 \\
37\end{array}$ & $\begin{array}{l}54 \\
75\end{array}$ & $\begin{array}{l}200 \\
323\end{array}$ & $\begin{array}{l}459 \\
698\end{array}$ \\
\hline $\begin{array}{l}\text { DOC } \ddagger \text { concentration in runoff } \\
\text { (forests, agricultural lands) }\end{array}$ & $\begin{array}{l}0.7 \\
1.4^{*} \\
2.8\end{array}$ & $\begin{array}{c}3.5 \\
6.9^{*} \\
14.0\end{array}$ & $\begin{array}{l}24 \\
26 \\
30\end{array}$ & $\begin{array}{l}50 \\
54 \\
60\end{array}$ & $\begin{array}{l}200 \\
200 \\
200\end{array}$ & $\begin{array}{l}459 \\
459 \\
459\end{array}$ \\
\hline
\end{tabular}

* Value used in final model.

$\dagger K=$ soil erodibility; $L S=$ soil topographic features; $C=$ vegetative cover factors; $P=$ agricultural practice factors.

$\ddagger$ Dissolved organic carbon.

estimated carbon fluxes at the Troy Dam up to the U.S.G.S. values. An increase in the assumed carbon concentration of bulk soils would have the same effect as increasing the enrichment ratio, but again no reasonable increase would be sufficient.

In any event, we do not believe that the model in its current configuration should be used as a quantitative predictor of sediment or organic carbon inputs to the tidal, freshwater portion of the Hudson River estuary. Nevertheless, the qualitative conclusions of the model remain robust as parameter values are varied.

\section{MODEL IMPROVEMENTS}

The GWLF model has proven to be a useful tool to elucidate the relative importance of the different landuse types in the Hudson River watershed as sources of organic carbon to the estuary. However, we see several areas for improvements. Perhaps the most glaring need is in the urban/suburban component of the model. Our use of this part of the model could be greatly improved by using actual data on the relative degree of urbanization in urban and suburban areas; we have no such data, and thus our parameterization is little more than a guess. Beyond this, however, the urban/suburban component of the model is simplistic and lacks some of the physical reality inherent in other parts of the GWLF model. This probably reflects the relative lack of "field" study of urban and suburban ecosystems. If these systems are as important influences on estuaries as the model suggests, they clearly should receive a great deal more study. Basic improvements in the model can only follow such study.

Another obvious improvement would be to model in-stream and in-river processes. Currently, transport of sediment from rural areas is controlled by the sediment delivery ration $(D) . D$ is estimated from watershed size, and thus transport of sediments in the model is in no way a function of any stream or river characteristic. Further, the model assumes that DOC behaves conservatively and is transported without consumption or reaction. However, from our respiration measurements (R. W. Howarth et al., unpublished data), we know that a significant percentage-perhaps a third-of the non-point-source organic carbon that enters the tidal, freshwater Hudson River estuary is consumed within the estuary. It seems likely that significant amounts of POC and DOC are consumed within the tributaries to the estuary as well. It should be possible to model such consumption as well as transport and sedimentation of particles and dissolved substances within the tributaries, using parameters such as water residence time and river slope. Such a model could replace the use of the sediment delivery ratio, and would be a step toward including more realistic spatial interactions of the various land-use types.

The application of the GWLF model to carbon transport in the Hudson basins would be improved by better parameterization of DOC in agricultural runoff, and for DOC in groundwaters from all land-use areas. We used data on DOC concentrations in runoff from agroecosystem studies in Mississippi (Schreiber and 
McGregor 1979) because we are unaware of a good data set more applicable to the Hudson Valley. However, note that the model estimates are not particularly sensitive to the assumed concentration of DOC in runoff (Table 5). For groundwaters, the GWLF assumes constant DOC concentrations regardless of the landuse in the source aquifer; it seems desirable to look for differences in groundwater DOC fluxes as a function of land-use type and to parameterize the model accordingly with data from the Hudson River watersheds.

Finally, we currently use average soil characteristics and aggregated land-use categories. Using a geographic information system (GIS), the model could be altered to make full use of detailed soil data and to couple these data on a fine scale with land-use data.

\section{SignifiCANCE OF FluXES to ESTUARINE Metabolism}

The GWLF model indicates that changes in land use have major effects on fluxes of carbon and suspended sediments to the Hudson River estuary, with agricultural land and suburban and urban areas exporting a disproportionate amount to the river. Presumably, fluxes to the estuary were much lower prior to European settlement. How have increased inputs of carbon and sediment affected metabolism of the estuary, and how might future changes in fluxes from terrestrial ecosystems change estuarine function?

Currently, rates of net primary production are low in the tidal, freshwater estuary due to extreme light limitation (Cole et al., in press). The shallow photic zone of the estuary is largely due to high turbidity from suspended particles (Stross and Sokol 1989). These particles rapidly settle out, and the continuing high turbidity probably reflects a continuously high input of eroded substances from terrestrial ecosystems (Stross and Sokol 1989). Thus, light limitation was probably much less before European settlement of the Hudson valley, and net primary production much greater and perhaps nutrient limited. Should inputs of eroded sediments decrease due to better management, we would expect net primary production to increase dramatically.

Our measured rates of whole-ecosystem respiration (R. W. Howarth et al., unpublished data) are sufficiently high as to indicate that a significant percentage of the allochthonous inputs of organic carbon from terrestrial ecosystems is being consumed within the estuary. This suggests that increased fluxes from terrestrial systems have resulted in higher rates of respiration as well as in lower rates of net primary production. It seems entirely possible that societal use of land in the Hudson watersheds has changed the estuary from predominantly autotrophic to predominantly heterotrophic metabolism. Presumably, dissolved oxygen concentrations are much lower than before European settlement.

We know little about the use of terrestrially derived carbon in energy flow in the Hudson estuary or about the relative quality of carbon from various sources. Is POC from eroded agricultural soils or DOC from forest runoff more easily metabolized by microorganisms? We simply do not know, and so we cannot easily determine how changes in terrestrial fluxes have altered heterotrophic pathways of energy flow. However, bacterial production within the estuary is very high at present, in fact higher than net primary production by algae, again indicating the heterotrophic nature of the estuary (Findlay et al., in press).

Increased fluxes from terrestrial systems may have effects beyond those on primary production and energy flow. Limburg and Schmidt (1990) have reported that alewife spawning in tributaries of the Hudson River estuary is inversely related to urbanization in the watersheds feeding the tributaries. We suspect that their statistical relationship may be a result of the increased suspended silt loads in the more urbanized and suburbanized areas. However, further study of this relationship is clearly warranted, and the observed relationship could result from other aspects of urbanization (toxic substances, etc.) or could merely be a result of a non-causative correlation. For instance, spawning may be better in the more shallow tributaries, which have been less urbanized historically because they are less navigable.

\section{Conclusions}

The GWLF model has proven to be a useful tool in exploring the non-point-source inputs of organic carbon and sediment to the tidal, freshwater Hudson River estuary. Limitations in the structure and parameterization make quantitative output from the model of questionable significance, yet the model predicts total water discharges, total sediment inputs, and total organic carbon inputs to the estuary to within $86 \%, 75 \%$, and $60 \%$, respectively, when compared with U.S.G.S. data taken at the Troy Dam. All model estimates appear somewhat low.

Qualitative conclusions from the model appear fairly robust. Urban and suburban areas and agricultural fields are the dominant sources of both organic carbon and total sediment, and increases or decreases in the area of either would be expected to alter fluxes of materials to the estuary. In addition, more intensive land use within urban and suburban regions would be expected to increase fluxes of both organic carbon and sediments. That is, fluxes are quite sensitive to changes in suburban areas from a low or moderate density of housing to high-density housing or commercial uses.

The effects of urbanization on movement of substances to aquatic ecosystems have received very little study, although Osborne and Wiley (1988) concluded that suburban development was at least as important as agriculture as a contributor of nutrients to surface waters in Illinois. Further direct studies of exports from urban and suburban lands are clearly desirable. 
Fluxes of carbon from terrestrial ecosystems to the estuary are sensitive to changes in precipitation. However, day-to-day and seasonal patterns in precipitation appear more important than total annual amount in controlling organic carbon fluxes. This result has implications for changes in precipitation patterns that might accompany global change.

Several lines of evidence now suggest that non-pointsource runoff from terrestrial ecosystems can have major influences on the metabolism and functioning of large estuaries. The challenge of managing large estuarine ecosystems therefore becomes one of managing entire large watersheds, and especially their urban/suburban and agroecosystem components. To do so will require more study of these large integrated watershedestuarine systems, and this in turn will demand stronger interactions among aquatic ecologists, terrestrial ecologists, and modelers. An exciting array of applications of basic ecology will be necessary.

\section{ACKNOWLEDGMENTS}

We thank Doug Haith for essential technical advice and assistance, Roxanne Marino, Jeff Levinton, and an anonymous reviewer for critical comments on the manuscript, and Si Levin for soliciting this paper. Primary funding was provided by the Hudson River Foundation for Science and Environmental Research, Inc., a New York not-for-profit corporation with its office located in New York City. We gratefully acknowledge their support and particularly the moral support of their Science Director, Dennis Suszkowski. Funding was also provided by the U.S. Environmental Protection Agency through a cooperative agreement with the Ecosystems Research Center at Cornell. The views expressed here do not necessarily reflect the beliefs or opinions of the Hudson River Foundation, the Environmental Protection Agency, or Cornell University, none of which assume any responsibility or liability for the contents or use of the information here published.

\section{Literature Cited}

Beaulac, M. N., and K. H. Reckow. 1982. An examination of land use-nutrient export relationships. Water Resources Bulletin 18:1013-1024.

Boynton, W. R., W. M. Kemp, and C. W. Keefe. 1982. A comparative analysis of nutrients and other factors influencing estuarine phytoplankton production. Pages 69-90 in V.S. Kennedy, editor. Estuarine comparisons. Academic Press, New York, New York, USA.

City of New York, Department of Environmental Protection, Bureau of Wastewater Treatment. 1987. New York harbor water quality survey. Water Quality Section, Wards Island, New York, New York, USA.

Cline, M. G., and R. L. Marshall. 1976. Soils of New York landscapes. Information Bulletin 119. New York State College of Agriculture and Life Sciences, Cornell University, Ithaca, New York, USA.

Cole, J. J., N. F. Caraco, and B. Peierls. In press. Phytoplankton primary production in the tidal, freshwater Hudson River, New York (USA). Verhandlungen der Internationalen Vereinigung für Theoretische und Angewandte Limnologie.

Cooper, J. C., F. R. Cantelmo, and C. E. Newton. 1988.
Overview of the Hudson River estuary. American Fisheries Society Monograph 4:11-24.

D’Elia, C. F., J. G. Sanders, and W. R. Boynton. 1986. Nutrient enrichment studies in a coastal plain estuary: phytoplankton growth in large-scale, continuous cultures. Canadian Journal of Fisheries and Aquatic Sciences 43:397406.

Findlay, S., M. L. Pace, D. Lints, J. J. Cole, N. F. Caraco, and B. Peierls. In press. Independence of bacterial and algal production in a heterotrophic ecosystem, the Hudson estuary. Limnology and Oceanography.

Fisher, S. G., and G. E. Likens. 1973. Energy flow in Bear Brook, New Hampshire: an integrative approach to stream ecosystem metabolism. Ecological Monographs 43:421-439.

Fruci, J. R., and R. W. Howarth. 1989. Carbon, nitrogen, and phosphorus loading to the tidal, freshwater portion of the Hudson River estuary from point and non-point sources: preliminary analyses. Technical report to the Hudson River Foundation, 40 West 20th Street, 9 th floor, New York, New York 10011 USA.

Garritt, R. H. 1990. The metabolism of a submersed macrophyte community in the tidal, freshwater Hudson River estuary. Thesis. Cornell University, Ithaca, New York, USA.

Gladden, J. B., F. R. Cantelmo, J. M. Croom, and R. Shapot. 1988. Evaluation of the Hudson River ecosystem in relation to the dynamics of fish populations. American Fisheries Society Monograph 4:37-52.

Haith, D. A. 1985. An event-based procedure for estimating monthly sediment yields. Transactions of the American Society of Agricultural Engineering 28:1916-1920.

Haith, D. A., and L. L. Shoemaker. 1987. Generalized watershed loading functions for stream-flow nutrients. Water Resources Bulletin 23:471-478.

Hamon, W. R. 1961. Estimating potential evapotranspiration. Proceedings of the American Society of Civil Engineers, Journal of the Hydraulics Division 87(HY3):107120.

Howarth, R. W. 1988. Nutrient limitation of net primary production in marine ecosystems. Annual Review of Ecology and Systematics 19:89-110.

Hydraulic Engineering Center. 1977. Storage, treatment, overflow, runoff model "STORM." 723-S8-L7520. United States Army Corps of Engineers, Davis, California, USA.

Kemp, W. M., W. R. Boynton, R. R. Twilley, J. C. Stevenson, and J. C. Means. 1983. The decline of submerged vascular plants in upper Chesapeake Bay: summary of results concerning possible causes. Marine Technology Society Journal 17:78-89.

Kemp, W. M., W. R. Boynton, R. R. Twilley, J. C. Stevenson, and L. G. Ward. 1984. Influences of submersed vascular plants on ecological processes in upper Chesapeake Bay. Pages 367-394 in V. S. Kennedy, editor. The estuary as a filter. Academic Press, New York, New York, USA.

Larsson, U. R., R. Elmgren, and F. Wulff. 1985. Eutrophication and the Baltic Sea: causes and consequences. Ambio 14:10-14.

Likens, G. E., F. H. Bormann, R. S. Pierce, and J. S. Eaton. 1985. The Hubbard Brook valley. Pages 9-39 in G. E. Likens, editor. An ecosystem approach to aquatic ecology. Springer-Verlag, New York, New York, USA.

Limburg, K. E., M. A. Moran, and W. H. McDowell. 1986. The Hudson River ecosystem. Springer-Verlag, New York, New York, USA.

Limburg, K. E., and R. E. Schmidt. 1990. Patterns of fish spawning in the Hudson River watershed: biological response to an urban gradient. Ecology 71:1238-1245.

Linsley, R. K., Jr., M. A. Kohler, and J. L. H. Paulhus. 1958. Hydrology for engineers. McGraw-Hill, New York, New York, USA.

McElroy, A. D., S. Y. Chiu, J. W. Nebgen, A. Alei, and F. 
W. Bennett. 1976. Loading functions for assessment of water pollution from nonpoint sources. EPA-600/2-76-151. United States Environmental Protection Agency, Washington, D.C., USA.

Mockus, V. 1972. Estimation of direct runoff from storm rainfall. National Engineering Handbook, section 4: hydrology. United States Soil Conservation Service, Washington, D.C., USA.

New York Crop Reporting Service. 1985. New York Agricultural Statistics-1984. New York State Department of Agriculture and Markets, Albany, New York, USA.

New York State Department of Environmental Conservation. 1981. The forest resources of New York: a summary assessment. Forest Resources Planning, New York State Department of Environmental Conservation, Albany, New York, USA.

Nixon, S. W., C. Oviatt, J. Frithsen, and B. Sullivan. 1986. Nutrients and the productivity of estuarine and coastal marine ecosystems. Journal of the Limnological Society of Southern Africa 12:43-71.

Nixon, S. W., and M. E. Q. Pilson. 1983. Nitrogen in estuarine and coastal marine ecosystems. Pages 565-648 in E. J. Carpenter and D. G. Capone, editors. Nitrogen in the marine environment. Academic Press, New York, New York, USA.

Officer, C. B., R. B. Biggs, J. Taft, L. E. Cronin, M. A. Tyler, and W. R. Boynton. 1986. Chesapeake Bay anoxia: origin, development, and significance. Science 232:22-27.

Ogrosky, H. O., and V. Mockus. 1964. Hydrology of agricultural lands. Pages 21-1-21-97 in V. T. Crow, editor. Handbook of applied hydrology. McGraw-Hill, New York, New York, USA.

Osborne, L. L., and M. J. Wiley. 1988. Empirical relationships between land use cover and stream water quality in an agricultural watershed. Journal of Environmental Management 26:9-27.

Price, K. S., D. A. Flemer, J. L. Taft, and G. B. Mackiernan. 1985. Nutrient enrichment of Chesapeake Bay and its impact on the habitat of striped bass: a speculative hypothesis. Transactions of the American Fisheries Society 114:97106.

Renfro, G. W. 1975. Use of erosion equation and sediment delivery ratios for predicting sediment yield. Pages 33-45 in Proceedings of the sediment-yield workshop. United States Department of Agriculture Sedimentation Laboratory, Oxford, Mississippi, USA.
Richardson C. W., G. R. Foster, and D. A. Wright. 1983. Estimation of erosion indices from daily rainfall amount. Transactions of the American Society of Agricultural Engineers 26:153-160.

Schlesinger, W. H., and J. M. Melack. 1981. Transport of organic carbon in the world's rivers. Tellus 33:172-187.

Schreiber, J. D., and K. C. McGregor. 1979. The transport and oxygen demand of organic carbon released to runoff from crop residue. Progress in Water Technology 11:253261.

Sheridan, J. M., C. V. Booram, Jr., and L. E. Asmussen. 1982. Sediment delivery ratios for a small coastal plain agricultural watershed. Transactions of the American Society of Agricultural Engineers 25:610-615.

Stewart, B. A., D. A. Woolhiser, W. H. Wischmeier, J. H. Caro, and M. H. Frere. 1976. Control of water pollution from cropland. Volume 1. EPA-600/2-75-026a. United States Environmental Protection Agency, Washington, D.C., USA.

Stross, R. G., and R. C. Sokol. 1989. Runoff and flocculation modify underwater light environment of the Hudson River estuary. Estuarine and Coastal Shelf Science 29:305-316.

Thurman, E. M. 1985. Humic substances in soil, sediment, and water: geochemistry, isolation, and characterization. John Wiley \& Sons, New York, New York, USA.

U.S.G.S. [United States Geological Survey]. 1980. Water resources data for New York, water year 1980. Volume 1: Eastern New York excluding Long Island. Water Resources Division, United States Geological Survey, Albany, New York, USA.

- 1981. Water resources data for New York, water year 1981. Volume 1: Eastern New York excluding Long Island. Water Resources Division, United States Geographical Survey, Albany, New York, USA.

U.S. Soil Conservation Service. 1975. Urban hydrology for small watersheds. Technical release number 55 . United States Department of Agriculture, Washington, D.C., USA.

Vanoni, V. A. 1975. Sedimentation engineering. American Society of Civil Engineers, New York, New York, USA.

Wischmeier, W. H., and D. D. Smith. 1978. Predicting rainfall erosion losses-a guide to conservation planning. Agricultural Handbook 537. United States Department of Agriculture, Washington, D.C., USA. 